\title{
World minerals trade: a comment
}

\author{
Phillip Crowson ${ }^{1,2}$ (D)
}

Received: 22 November 2018 / Accepted: 11 March 2019 / Published online: 1 April 2019

(C) The Author(s) 2019

\begin{abstract}
This purely descriptive note discusses various aspects of world trade in minerals. It is not aimed at specialist mineral economists who may extract any detailed trade figures they require from the United Nations' Comtrade database. Rather it is directed to all those who might use readily available aggregate data on minerals trade for broad analyses of the minerals industry. It starts from the most commonly quoted estimates of minerals trade before looking at some of the issues surrounding those measures and highlighting some of the pitfalls involved. It then examines both the product composition and geographical origins of minerals trade and how it has developed over the past half century. The concluding sections turn to a discussion of the merits and demerits of various measures of mineral dependence.
\end{abstract}

Keywords Mineral trade $\cdot$ Mineral dependence $\cdot$ Exports

JEL F14 $\cdot$ L72. $\cdot$ N50

\section{Introduction}

The Comtrade database allows the analysis of trade data on two bases, the Harmonised System and the Standard International Trade Classification (SITC). This note is based on the SITC, but there are common pitfalls in defining the scope of the minerals industry whichever basis is used. The next section delves into the data in some detail, as such burrowing is necessary to an understanding of the meaning and relevance of the aggregate measures. It is in no way a criticism of the World Bank or other providers of aggregate trade data, but rather an explanation of the data. The devil, as always, is in the detail. That may be well understood by specialist researchers into the minerals industry, but such rare individuals are not the target audience for this note.

Perhaps the most widely quoted broad measure of minerals trade in general discussion is that of the World Bank, as published, for example, in its World Development Indicators. This covers total exports in divisions 27 (crude fertilisers, minerals

Phillip Crowson

Phillip.crowson@btinternet.com

1 Centre for Energy, Petroleum and Mineral Law and Policy, University of Dundee, Nethergate, Dundee DD1 4HN, Scotland

2 Reigate, UK not elsewhere specified), 28 (metalliferous ores and scrap) and 68 (non-ferrous metals) of Revision 4 of the SITC. The first column of the upper portion of Table 1 shows the figures for $2016,{ }^{1}$ as recorded in the United Nations' Statistical Division's Comtrade.

The total of $\$ 525.2$ billion excludes the exports of a number of mineral producing countries, such as Papua New Guinea and the Democratic Republic of Congo, for which Comtrade has no data.

Some commentators (for example, Ericcson and Löf 2017) widen the definition of mineral trade to include pearls, precious stones and non-monetary gold (divisions 667 and 971 of SITC Rev.4). The totals for these are substantial, as shown in the lower portion of Table 1 and their inclusion greatly increases the value of mineral exports to $\$ 985$ billion in 2016 .

An important caveat about using total exports as a measure is that they embrace re-exports as well as domestic exports. Re-exports are relatively insignificant for the narrower definition, accounting for little more than $2 \%$ of the published global total exports. They are far more important for precious stones and non-monetary gold, making up almost $20 \%$ of the total exports of these products. That means that re-

\footnotetext{
${ }^{1}$ The table includes 2015 data for Guinea, New Caledonia and Zambia as their figures for 2016 have not yet (July 20,2018) been included in the UN analyses. Their total exports amounted to $\$ 0.04$ billion in division $27, \$ 1.12$ billion in division 28 and $\$ 5.17$ billion in division 68 .
} 
Table 1 World exports of selected mineral products in 2016 in US\$ billion

\begin{tabular}{lccc}
\hline & Total exports & Re-exports & Domestic exports \\
\hline Div. 27 & 29.4 & 0.2 & 29.2 \\
Div. 28 & 219.6 & 1.5 & 218.2 \\
Div. 68 & 276.1 & 9.2 & 267.0 \\
Subtotal ores and metals & 525.2 & 10.9 & 514.3 \\
Div.667 & 143.7 & 52.3 & 91.4 \\
Div.971 & 316.0 & 37.5 & 278.5 \\
Subtotal precious metals and non-monetary gold & 459.7 & 89.8 & 369.9 \\
Overall Total & 984.9 & 100.7 & 892.8 \\
\hline
\end{tabular}

Source: Comtrade exports account for just over $10 \%$ of the overall total shown in Table 1. In practice, re-exports are probably much greater than shown because many countries do not separately distinguish them. Looking beyond global figures, re-exports are important for some individual countries so that their inclusion can distort inter-country comparisons of export dependence. Domestic exports, as shown in the third column of Table 1, are a much cleaner measure, both for inter-country and for temporal comparisons.

\section{The product composition of mineral exports}

More importantly, the definition of minerals trade shown in Table 1, whether on the narrow or broader basis, includes a range of products that are not normally regarded as being produced by the minerals industry and excludes some significant products that clearly are. Table 2 shows the composition of the exports of ores and metals covered in divisions 27, 28 and 68, excluding the 2015 figures for the three countries given in Table 1. The upper portion of the table, with the items contained in subtotal A, gives the products of the mineral industry, and the lower portion, with subtotal B, other mineral products.

Whereas trade in iron and steel is not treated as coming from the minerals industry, the total of Table 1 rather illogically includes significant trade in ferrous waste and scrap. Trade in other forms of metalliferous waste and scrap, which is mainly engendered in minerals consuming rather than producing countries, is also included. Total exports of waste and scrap (divisions 282, 288 and 2892) amounted to $\$ 59.8$ billion in 2016, and domestic exports to $\$ 59$ billion. These exports are major sources of raw materials in some countries, often competing with virgin materials, but their inclusion can distort the data as indications of the contributions to economic activity from mining.

Division 68 of the SITC includes semi manufactures as well as primary metals. By far the greater share of these is produced in minerals consuming countries, and they are not normally treated as part of the mining and metals industry. This is most relevant for copper as semi manufactures make up $46 \%$ of the exports included in division 682. Aluminium (division 684), which accounts for $20 \%$ of the total domestic exports in the table, is a manufactured product based on the raw materials included in division 285. Its economics depend not just on mining but predominantly on the availability of low-cost energy. There is no more justification for including it than there would be for iron and steel and it is illogical that the former is included but the latter is not.

Table 2 shows that scrap, semimanufactures and aluminium make up two-fifths of its totals. ${ }^{2}$ Whereas the overall trends in the two subtotals may, or may not be similar over time, measures of mineral dependency based on subtotal A are likely to differ considerably in many countries from measures based on the total of subtotals A and B.

Turning to precious stones and non-monetary gold, Table 3 shows the product composition of divisions 667 and 971 . Again, these include products that are not strictly produced by the mining industry such as pearls (division 6671) and synthetic gemstones (division 6674). These are included in Table 3's subtotal B.

Most diamonds are exported from the mining countries in unprocessed form and much of their added value comes from cutting and polishing elsewhere. The domestic exports of countries identified by the US Geological Survey as mining gem diamonds, and for which Comtrade publishes trade data, amounted to $\$ 16.2$ billion. ${ }^{3}$ The diamond exports of mining countries are separately distinguished in the top portion of Table 3. The domestic exports of the major diamond cutting countries of Belgium,

\footnotetext{
${ }^{2}$ The totals of Table 2 differ from those of Table 1, because they do not include the 2015 figures for Guinea, New Caledonia and Zambia.

${ }^{3}$ Gem diamond production in 2015 as published in Table 11 of the gemstones chapter of the 2015 Minerals Yearbook, US Geological Survey (United States Geological Survey 2018)
} 
Table 2 The product composition of world exports of ores and metals in 2016 in US\$ billion

\begin{tabular}{|c|c|c|c|c|}
\hline \multicolumn{2}{|l|}{ SITC4 code } & \multirow{2}{*}{$\frac{\text { Total Exports }}{3.36}$} & \multirow{2}{*}{$\frac{\text { Re-exports }}{0.01}$} & \multirow{2}{*}{$\frac{\text { Domestic export }}{3.35}$} \\
\hline 272 & Fertilisers, crude, other than those of division 56 & & & \\
\hline 273 & Stone, sand and gravel & 8.76 & 0.02 & 8.74 \\
\hline 274 & Sulphur and unroasted iron pyrites & 1.79 & 0.00 & 1.79 \\
\hline 277 & $\begin{array}{l}\text { Natural abrasives, not elsewhere specified } \\
\text { (including industrial diamonds) }\end{array}$ & 1.23 & 0.11 & 1.12 \\
\hline 278 & Other crude minerals & 14.23 & 0.11 & 14.13 \\
\hline 281 & Iron ore and concentrates & 69.53 & 0.02 & 69.51 \\
\hline 283 & Copper ores and concentrates; copper mattes; cement copper & 45.67 & 0.57 & 45.10 \\
\hline 284 & $\begin{array}{l}\text { Nickel ores and concentrates; nickel mattes, } \\
\text { nickel oxide sinters and other intermediate products of nickel metallurgy }\end{array}$ & 3.81 & 0.002 & 3.81 \\
\hline 285 & Aluminium ores and concentrates (including alumina) & 12.08 & 0.02 & 12.06 \\
\hline 286 & Uranium or thorium ores and concentrates & 0.55 & 0.00 & 0.55 \\
\hline 287 & Ores and concentrates of base metals, not elsewhere specified & 21.29 & 0.05 & 21.23 \\
\hline 2891 & Precious metal ores and concentrates & 5.79 & 0.00 & 5.79 \\
\hline 6811 & $\begin{array}{l}\text { Silver (including base metals clad with silver), } \\
\text { unwrought, unworked or semi-manufactured }\end{array}$ & 18.04 & 2.10 & 15.94 \\
\hline 6812 & $\begin{array}{l}\text { Platinum and other metals of the platinum group } \\
\text { (including metals clad with platinum or other metals } \\
\text { of the platinum group), unwrought, unworked or semi-manufactured }\end{array}$ & 21.47 & 2.14 & 19.33 \\
\hline 6821 & $\begin{array}{l}\text { Copper, refined and unrefined; copper anodes } \\
\text { for electrolytic refining; copper alloys, unwrought }\end{array}$ & 45.97 & 0.57 & 45.40 \\
\hline 6831 & Nickel and nickel alloys, unwrought (excluding electroplating anodes) & 8.86 & 0.11 & 8.75 \\
\hline 6851 & Lead and lead alloys, unwrought & 5.45 & 0.03 & 5.42 \\
\hline 6861 & Zinc and zinc alloys, unwrought & 10.60 & 0.35 & 10.26 \\
\hline 6871 & Tin and tin alloys, unwrought & 4.01 & 0.16 & 3.85 \\
\hline \multirow[t]{2}{*}{689} & Miscellaneous non-ferrous base metals employed in metallurgy, and cermets & 6.43 & 0.13 & 6.30 \\
\hline & Subtotal A for ores and metals & 308.92 & 6.50 & 302.42 \\
\hline 682 other & Copper semi manufactures & 40.43 & 1.24 & 39.20 \\
\hline 683 other & Nickel semi manufactures & 4.37 & 0.09 & 4.28 \\
\hline 685 other & Lead semi manufactures & 0.39 & 0.00 & 0.39 \\
\hline 686 other & Zinc semi manufactures & 0.88 & 0.01 & 0.87 \\
\hline 687 other & Tin semi manufactures & 0.45 & 0.05 & 0.40 \\
\hline 684 & Aluminium & 103.60 & 2.18 & 101.41 \\
\hline 282 & Ferrous waste and scrap; remelting scrap ingots of iron or steel & 24.21 & 0.24 & 23.96 \\
\hline 288 & Non-ferrous base metal waste and scrap, not elsewhere specified & 27.70 & 0.16 & 27.54 \\
\hline \multirow[t]{3}{*}{2892} & $\begin{array}{l}\text { Waste and scrap of precious metal (other than gold) } \\
\text { or of metals clad with precious metal (other than gold) }\end{array}$ & 7.89 & 0.40 & 7.49 \\
\hline & Subtotal B for ores and metals & 209.93 & 4.38 & 205.55 \\
\hline & Total for ores and metals & 518.85 & 10.88 & 507.97 \\
\hline
\end{tabular}

Source: Comtrade

India and Israel collectively account for $\$ 55.6$ billion, or $81 \%$, of the $\$ 68.5$ billion of the domestic exports by remaining countries shown in the lower portion of Table 3. A further share comes from semi-manufactured stones in industrial nations. Domestic exports of other precious stones from mining countries are similarly overstated, but to nothing like the same extent as for diamonds.

The domestic exports of gold shown in Table 3 include a substantial quantity of trade in existing aboveground stocks as well as semi-manufactured forms. Switzerland, the UK, Hong Kong, Singapore and the United Arab Emirates supplied almost half the total domestic exports of $\$ 278.46$ billion. After deducting the domestic exports of a further group of industrial countries without a significant gold mining industry, the exports of newly mined gold from mining countries were much nearer to $\$ 100$ billion, the value separately distinguished in the top part Table 3. As a rough check, the total value of global gold production in 2016 was approximately $\$ 125$ billion. ${ }^{4}$ Some was exported in unprocessed form and is included in section 28 shown in Table 2, and some will have been retained in the producing countries.

In summary, only one-third of global domestic exports of precious stones and non-monetary gold (subtotal $\mathrm{A}$ in Table 3 or $\$ 121.42$ billion) should be counted

\footnotetext{
${ }^{4}$ Global output of $3221.6 \mathrm{t}$, and a spot price of $\$ 1248.6$ / troy ounce in 2016, taken from World Metal Statistics 2018, World Bureau of Metal Statistics, Ware, 2018. There are 31,104 troy ounces in $1 \mathrm{t}$.
} 
Table 3 The product composition of world exports of precious stones and non-monetary gold in 2016 in US\$ billion

\begin{tabular}{|c|c|c|c|c|}
\hline \multicolumn{2}{|l|}{ SITC4 code } & \multirow{2}{*}{ Total exports } & \multirow{2}{*}{$\frac{\text { Re-exports }}{0.32}$} & \multirow{2}{*}{$\frac{\text { Domestic export }}{16.20}$} \\
\hline 6672 part & $\begin{array}{l}\text { Diamonds (other than sorted industrial diamonds), } \\
\text { whether or not worked, but not mounted or set. Mining countries. }\end{array}$ & & & \\
\hline 6673 & $\begin{array}{l}\text { Precious stones (other than diamonds) and semiprecious } \\
\text { stones, whether or not worked or graded but not strung, } \\
\text { mounted or set; ungraded precious stones (other than diamonds) } \\
\text { and semiprecious stones, temporarily strung for convenience of transport }\end{array}$ & 9.69 & 4.47 & 5.22 \\
\hline \multirow[t]{2}{*}{97101 part } & $\begin{array}{l}\text { Gold (including gold plated with platinum), non-monetary, } \\
\text { unwrought/in semi-manufactured forms/in powder form. Mining countries. }\end{array}$ & 100.00 & 0 & 100.00 \\
\hline & Subtotal A for precious stones and non-monetary gold & 126.21 & 4.79 & 121.42 \\
\hline 6671 & Pearls & 2.46 & 1.84 & 0.62 \\
\hline 6674 & Synthetic or reconstructed precious and semiprecious stones & 1.26 & 0.37 & 0.89 \\
\hline 6672 part & $\begin{array}{l}\text { Diamonds (other than sorted industrial diamonds), whether } \\
\text { or not worked, but not mounted or set. Remaining countries. }\end{array}$ & 113.77 & 45.26 & 68.51 \\
\hline \multirow[t]{3}{*}{97101 part } & $\begin{array}{l}\text { Gold (including gold plated with platinum), non-monetary, } \\
\text { unwrought/in semi-manufactured forms/in powder form. Remainder }\end{array}$ & 216.00 & 37.54 & 178.46 \\
\hline & Subtotal B for precious stones and non-monetary gold & 333.49 & 85.01 & 248.48 \\
\hline & Total for precious stones and non-monetary gold & 459.70 & 89.80 & 369.90 \\
\hline
\end{tabular}

Source: Comtrade

as exports of newly mined mineral products. That is just over $26 \%$ of the total exports of these products that are shown in Table 1.
Some significant mineral products are excluded from the definitions of mineral exports covered so far. Table 4 shows the possible contenders, of which the largest is coal. Coal,

Table 4 World exports of other mineral products in 2016 in US\$ billion

\begin{tabular}{|c|c|c|c|c|}
\hline SITC4 code & & Total exports & Re-exports & Domestic exports \\
\hline 321 & Coal, whether or not pulverised, but not agglomerated & 71.59 & 0.00 & 71.59 \\
\hline 322 & Briquettes, lignite and peat & 3.36 & 0.01 & 3.35 \\
\hline 325 & $\begin{array}{l}\text { Coke and semi-coke (including char) of coal, } \\
\text { of lignite or of peat, whether or not agglomerated; retort carbon }\end{array}$ & 4.53 & 0.03 & 4.50 \\
\hline 522 & Inorganic chemical elements, oxides and halogen salts & 41.23 & 0.34 & 40.89 \\
\hline 523 & Salts and peroxysalts, of inorganic acids and metals & 19.58 & 0.24 & 19.34 \\
\hline 5622 & Mineral or chemical fertilisers, phosphatic & 1.42 & 0.00 & 1.42 \\
\hline 5623 & $\begin{array}{l}\text { Mineral or chemical fertilisers, potassic } \\
\text { (other than crude natural potassium salts) }\end{array}$ & 9.69 & 0.36 & 9.33 \\
\hline 6611 & $\begin{array}{l}\text { Quicklime, slaked lime and hydraulic lime } \\
\text { (other than calcium oxide and hydroxide of subgroup 522.6) }\end{array}$ & 0.90 & 0.00 & 0.90 \\
\hline 6612 & $\begin{array}{l}\text { Portland cement, aluminous cement, slag cement, } \\
\text { super sulphate cement and similar hydraulic cements, } \\
\text { whether or not coloured or in the form of clinkers. }\end{array}$ & 8.94 & 0.05 & 8.89 \\
\hline 6613 & Monumental or building stone, worked, and articles thereof. & 14.03 & 0.14 & 13.89 \\
\hline 662 & Clay construction materials and refractory construction materials & 24.94 & 0.16 & 24.78 \\
\hline 6631 & $\begin{array}{l}\text { Millstones, grindstones, grinding wheels and the like, } \\
\text { without frameworks, for grinding, sharpening, polishing, } \\
\text { trueing or cutting hand sharpening or polishing stones } \\
\text { and parts thereof, of natural stone, } \\
\text { of agglomerated natural or artificial abrasives. }\end{array}$ & 4.17 & 0.06 & 4.11 \\
\hline \multirow[t]{2}{*}{66352} & $\begin{array}{l}\text { Exfoliated vermiculite, expanded clays, foamed slag \& } \\
\text { similar expanded mineral materials (including intermixtures thereof) }\end{array}$ & 0.31 & 0.00 & 0.31 \\
\hline & Total other mineral products & 204.69 & 1.39 & 203.30 \\
\hline
\end{tabular}

Source: Comtrade 
Table 5 Summary of world exports of all mineral products in 2016, US\$ billion

\begin{tabular}{lccl}
\hline & Total exports & Re-exports & Domestic exports \\
\hline Table 2 subtotal A & 308.92 & 6.50 & 302.42 \\
Table 3 subtotal A & 126.21 & 4.79 & 121.42 \\
Table 4 total & 204.69 & 1.39 & 203.3 \\
& & & \\
Total Mineral exports & 639.82 & 12.68 & 627.14 \\
& & & \\
Table 2 subtotal B & 209.93 & 4.38 & 205.55 \\
Table 3 subtotal B & 333.49 & 85.01 & 248.48 \\
Overall total & 1183.24 & 101.87 & 1081.17 \\
\hline
\end{tabular}

Source: Tables $2-4$

Table 6 The geographical origins of world exports of mineral products in 2016

\begin{tabular}{|c|c|c|}
\hline & $\$$ billion & $\%$ of total \\
\hline \multicolumn{3}{|c|}{ Total: Sections 27, 28 and 68} \\
\hline Australia & 59.79 & 11.77 \\
\hline USA & 31.90 & 6.28 \\
\hline Chile & 30.72 & 6.05 \\
\hline Germany & 30.66 & 6.04 \\
\hline Canada & 24.18 & 4.76 \\
\hline China & 23.65 & 4.66 \\
\hline Brazil & 21.18 & 4.17 \\
\hline Russian Federation & 18.54 & 3.65 \\
\hline South Africa & 16.57 & 3.26 \\
\hline Peru & 15.54 & 3.06 \\
\hline Japan & 14.92 & 2.94 \\
\hline UK & 13.59 & 2.68 \\
\hline Netherlands & 10.82 & 2.13 \\
\hline Rep. of Korea & 10.25 & 2.02 \\
\hline Mexico & 10.15 & 2.00 \\
\hline \multicolumn{3}{|l|}{ Subtotal A of Table 2} \\
\hline Australia & 55.94 & 18.50 \\
\hline Chile & 29.57 & 9.78 \\
\hline Brazil & 19.57 & 6.47 \\
\hline Peru & 15.16 & 5.01 \\
\hline South Africa & 14.65 & 4.85 \\
\hline Canada & 13.93 & 4.61 \\
\hline USA & 12.14 & 4.02 \\
\hline Russian Federation & 10.66 & 3.53 \\
\hline China & 7.96 & 2.63 \\
\hline Mexico & 7.66 & 2.53 \\
\hline Germany & 6.95 & 2.30 \\
\hline UK & 6.88 & 2.27 \\
\hline Japan & 6.86 & 2.27 \\
\hline Indonesia & 6.38 & 2.11 \\
\hline \multicolumn{3}{|c|}{ Total mineral exports of Table 5} \\
\hline Australia & 86.55 & 16.42 \\
\hline China & 36.00 & 6.83 \\
\hline Chile & 31.44 & 5.97 \\
\hline Russian Federation & 29.03 & 5.51 \\
\hline USA & 26.88 & 5.10 \\
\hline Canada & 25.27 & 4.79 \\
\hline Brazil & 22.05 & 4.18 \\
\hline Indonesia & 21.63 & 4.10 \\
\hline South Africa & 21.26 & 4.03 \\
\hline Germany & 15.71 & 2.98 \\
\hline Peru & 15.58 & 2.96 \\
\hline Japan & 10.67 & 2.02 \\
\hline
\end{tabular}

lignite and peat (divisions 321 and 322) are undeniably mineral products, with similar supply characteristics to other minerals. The inclusion of coke (division 325) is more debatable as most coke ovens are located in mineral consuming countries. Many of the chemicals of divisions 522 and 523 are the first-stage products of mining and are analogous to primary metals. So too are simple phosphatic and potassic fertilisers (divisions 5622 and 5623). Lime, building stone and cement (divisions 6611 to 6613 ) are also primary products of mining and quarrying, as are the manufactures of divisions 662 and 663 included in the table.

The products of division 66 are the only mineral products of many countries. The exclusion of those, as well as the other products listed in Table 4, from estimates of mineral exports used in international comparisons and in measures of dependence can bias any resulting conclusions.

Drawing the threads together, Table 5 shows the total exports of newly mined and first-stage processed mineral products. The rounded totals amount to $\$ 640$ billion for all exports and $\$ 627$ billion for domestic exports. These figures compare with the overall levels of $\$ 1182$ billion for total exports of all the products included in Tables 2-4 inclusive, and $\$ 1081$ billion of domestic exports, as shown in the last line of Table 5.

The last line of Table 5 may give an indication of the overall importance of all mineral products in world trade, but for the reasons given in the previous discussion, it tends to exaggerate the importance of export trade for mineral producing countries.

The relative importance of the different products can change dramatically over time with shifts in relative prices, although there is a broad tendency for prices of the major products to move in step in response to fluctuating business conditions.

\section{The geographical origins of mineral exports}

So much for the product composition of mineral exports in 2016. A substantial proportion of exports comes from only a few countries. This is illustrated in Table 6, which shows the leading exporters of the products listed in Tables 2-4. The top part of the table shows total exports of SITC sections 27, 28 and 68, the measure published in the World Bank's World Development Indicators. ${ }^{5}$ The middle portion gives the figures for subtotal A of Table 2 (i.e. excluding aluminium, semi-finished non-ferrous metals, and waste and scrap of all types), and the bottom portion contains figures for the wider definition of total mineral exports given in Table 5. This last excludes newly mined gold, because its geographical origins are unavailable.

Only countries with at least $2 \%$ of the relevant totals are included in the table. The 16 exporters in the top third of the

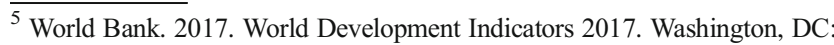
World Bank.
} 
Fig. 1 World exports of ores and minerals, 1962-2016 in US\$

billion. Source; World

Development Indicators. World

Bank

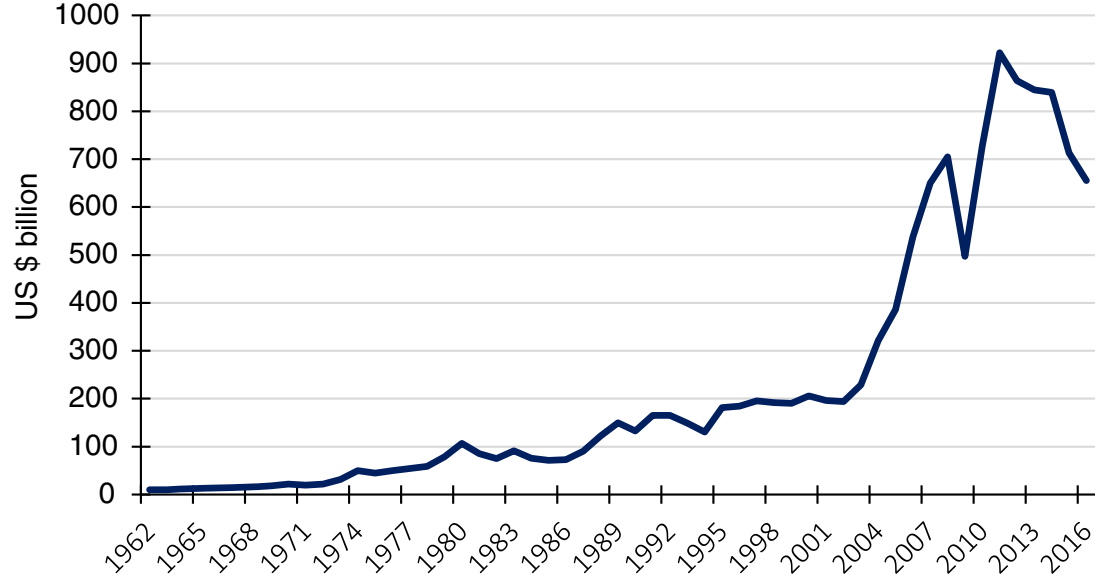

table accounted for $65 \%$ of global trade, the 15 in the middle portion for $72 \%$ and the 12 in the bottom third also for $65 \%$. Australia is by far the largest mineral exporter on any basis but the USA drops from second to seventh place between the broad and narrower definitions because it is a large exporter of aluminium and non-ferrous semi-manufactures. China's importance increases when the wider definition of mineral trade is adopted. The inclusion of the countries for which 2016 statistics are not available would not dramatically alter the rankings. One interesting feature is the importance of countries like Germany, Japan, UK, Korea and the Netherlands whose mining industries are relatively unimportant, but which are major shippers of unwrought metals, including silver and platinum products.

\section{Relative trends in mineral exports}

The trend in world exports of ores and minerals between 1962 and 2016 is shown in money terms in Fig. 1. The underlying data are derived from the estimates of world merchandise exports, as published in World Development Indicators, multiplied by the shares of ores and metals in that trade taken from the same source.

Much of the growth from 2002 to 2012 and the subsequent decline reflected changes in prices rather than movements in the volume of trade. Attention tends to focus, however, not on trends in the absolute levels of world exports of ores and minerals but on their shares of total merchandise trade. Accordingly, Fig. 2 shows the share of exports of products in sections 27, 28 and 68 (of SITC Rev.3) in global merchandise exports, as published in the World Bank's World Development Indicators. In the world as a whole, this was on an erratically declining trend from the late 1960 s to the early 2000s. This development conditioned much analysis of, and thinking about, the role of mineral production and trade in economic development. Subsequently, the share rose in step with the surge in prices and output of the early 2000s onwards.

Source: World Bank (https://data.worldbank.org/indicator/ TX.VAL.MMTL.ZS.UN.), derived from Comtrade database of the United Nations Statistical Division. Last updated June 26, 2018.
Fig. 2 World exports of ores and metals as a $\%$ of total merchandise exports, 1962-2017. Source: World Bank (https://data. worldbank.org/indicator/TX. VAL.MMTL.ZS.UN.), derived from Comtrade database of the United Nations Statistical Division. Last updated June 26, 2018

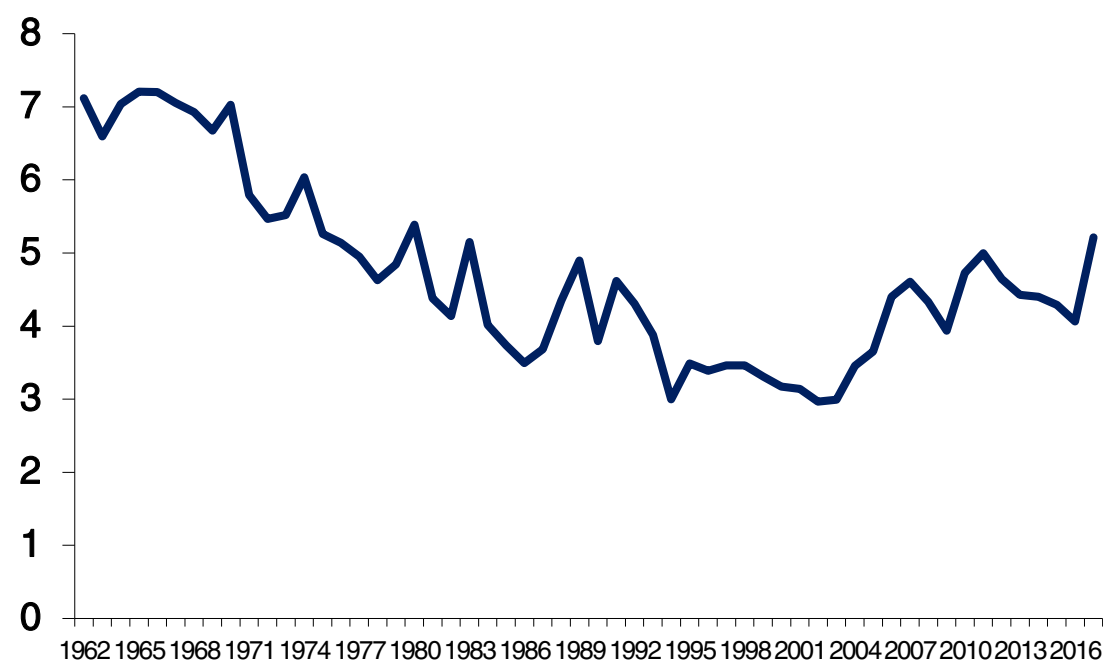


Fig. 3 Exports of ores and metals as a $\%$ of total merchandise exports of selected countries, 1962-2017. Source: World Bank (https://data.worldbank.org/ indicator/TX.VAL.MMTL.ZS. UN.), derived from Comtrade database of the United Nations Statistical Division. Last updated June 26, 2018

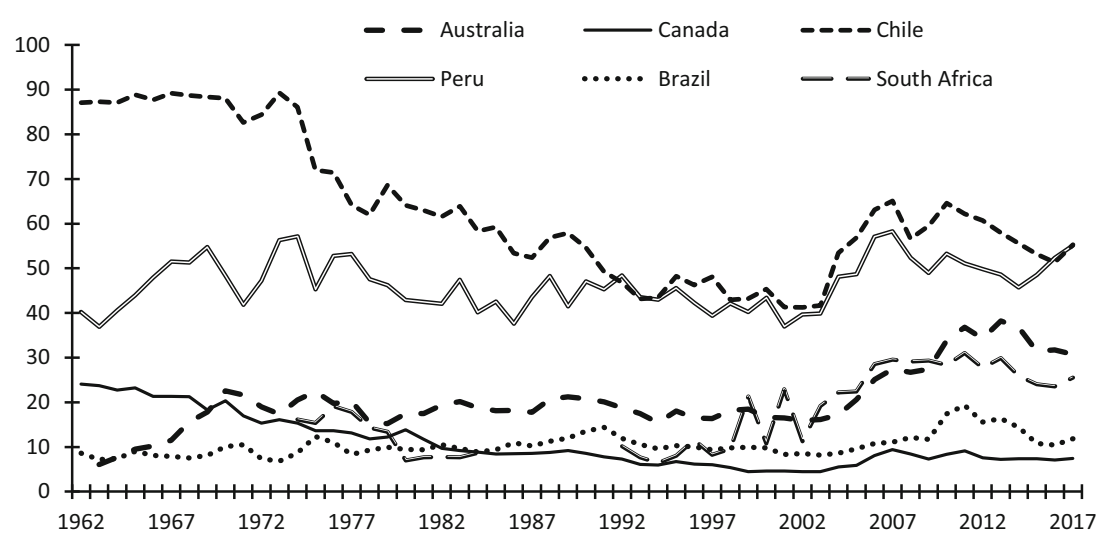

This overall picture masks substantial variations in the experiences of individual exporting countries. Moreover, it relates exports of minerals to merchandise exports from all countries, regardless of whether or not they have any mineral exports. Figure 3 demonstrates the variety of experience with the trends in shares of the six major mineral exporting countries that collectively accounted for $49 \%$ of the total on the narrower definition of subtotal A of Table 2. The data for South Africa are incomplete.
Source: World Bank (https://data.worldbank.org/indicator/ TX.VAL.MMTL.ZS.UN.), derived from Comtrade database of the United Nations Statistical Division. Last updated June 26, 2018.

None displayed exactly the same trend as the global average, although Chile's trend is similar and several experienced rising shares from the early 2000 s.

Moving from trends to cross-country comparisons, Fig. 4 shows the percentage shares of minerals in total domestic

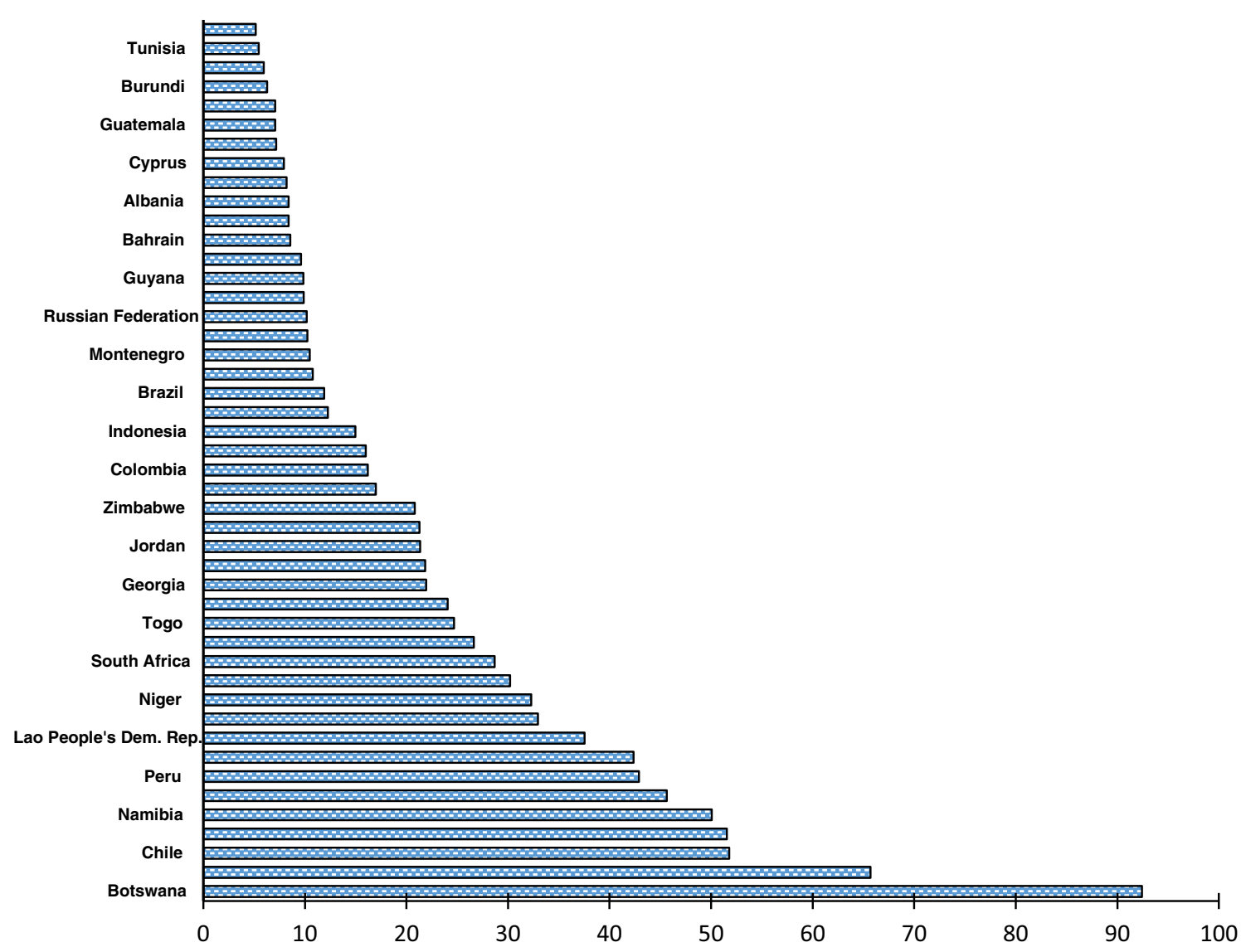

Fig. 4 The percentage share of minerals in total exports in 2016. Source: Comtrade 
Table 7 Comparative measures of the share of minerals in total exports in 2016

\begin{tabular}{|c|c|c|}
\hline & Fig. 3 basis & World Bank basis \\
\hline Botswana & 92.4 & 4.1 \\
\hline Zambia $^{\text {(a) }}$ & n.a. & 78.0 \\
\hline Mongolia & 65.7 & 54.2 \\
\hline Guinea $^{\text {(a) }}$ & n.a. & 61.0 \\
\hline Chile & 51.8 & 51.3 \\
\hline Jamaica & 51.6 & 9.7 \\
\hline Namibia & 50.1 & 23.0 \\
\hline Australia & 45.6 & 31.7 \\
\hline Peru & 42.9 & 52.3 \\
\hline Mauritania & 42.4 & 49.3 \\
\hline Lao People's Dem. Rep. & 37.5 & 38.6 \\
\hline New Caledonia ${ }^{\text {(a) }}$ & n.a. & 37.0 \\
\hline Bolivia & 33.0 & 36.5 \\
\hline Niger & 32.3 & 33.5 \\
\hline Armenia & 30.2 & 38.0 \\
\hline South Africa & 28.7 & 23.6 \\
\hline Madagascar & 26.6 & 25.8 \\
\hline Togo & 24.7 & 14.8 \\
\hline Rwanda & 24.0 & 27.9 \\
\hline Georgia & 21.9 & 23.9 \\
\hline Senegal & 21.8 & 7.6 \\
\hline Jordan & 21.4 & 8.8 \\
\hline State of Palestine & 21.3 & 6.2 \\
\hline Zimbabwe & 20.8 & 29.0 \\
\hline Mozambique & 17.0 & 32.6 \\
\hline Colombia & 16.2 & 1.2 \\
\hline Kazakhstan & 16.0 & 14.8 \\
\hline Indonesia & 15.0 & 5.7 \\
\hline Morocco & 12.3 & 6.5 \\
\hline Brazil & 11.9 & 10.5 \\
\hline Bulgaria & 10.8 & 11.6 \\
\hline Montenegro & 10.5 & n.a. \\
\hline Belarus & 10.3 & 1.2 \\
\hline Russian Federation & 10.2 & 6.6 \\
\hline
\end{tabular}

a: The World Bank measure is for 2015

Source: Comtrade and World Development Indicators merchandise exports on the broad definition of total mineral exports from Table 5, but without the contribution of gold. It covers all the countries for which 2016 data are available whose mineral share exceeded 5\%. Zambia, Guinea, New Caledonia, Papua New Guinea and the DRC also rank amongst the most mineral-dependent countries, but their data for 2016 are not available.

In many instances, the shares shown in Fig. 4 differ considerably from those published by the World Bank in World Development Indicators. This reflects both their different coverage of mineral trade and the use of different measures of total trade. The World Bank uses total exports whereas Fig. 3 is based on domestic exports, net of reexports. Moreover, the World Bank uses an earlier classification of trade (SITC 3) than this paper (SITC 4). Table 7 compares the two measures for all countries whose shares of minerals exceeded $10 \%$ on the measure used in this paper.

In most, but not all, instances, the dependence on minerals is greater on the basis used in Fig. 4 than on the World Bank basis. Yet, although the share of minerals in total exports is widely used as an indicator of a country's dependence on the mining industry, neither series may be the best measure. That is because the importance of trade varies considerably between countries. One may have a very high share of minerals in its exports but a low dependence on international trade, whereas another's economy may rely heavily on trade as well as having a large share of mineral products in its exports. Accordingly, Fig. 5 shows the share of mineral exports, on the Fig. 4 basis, in gross domestic product (GDP) for the

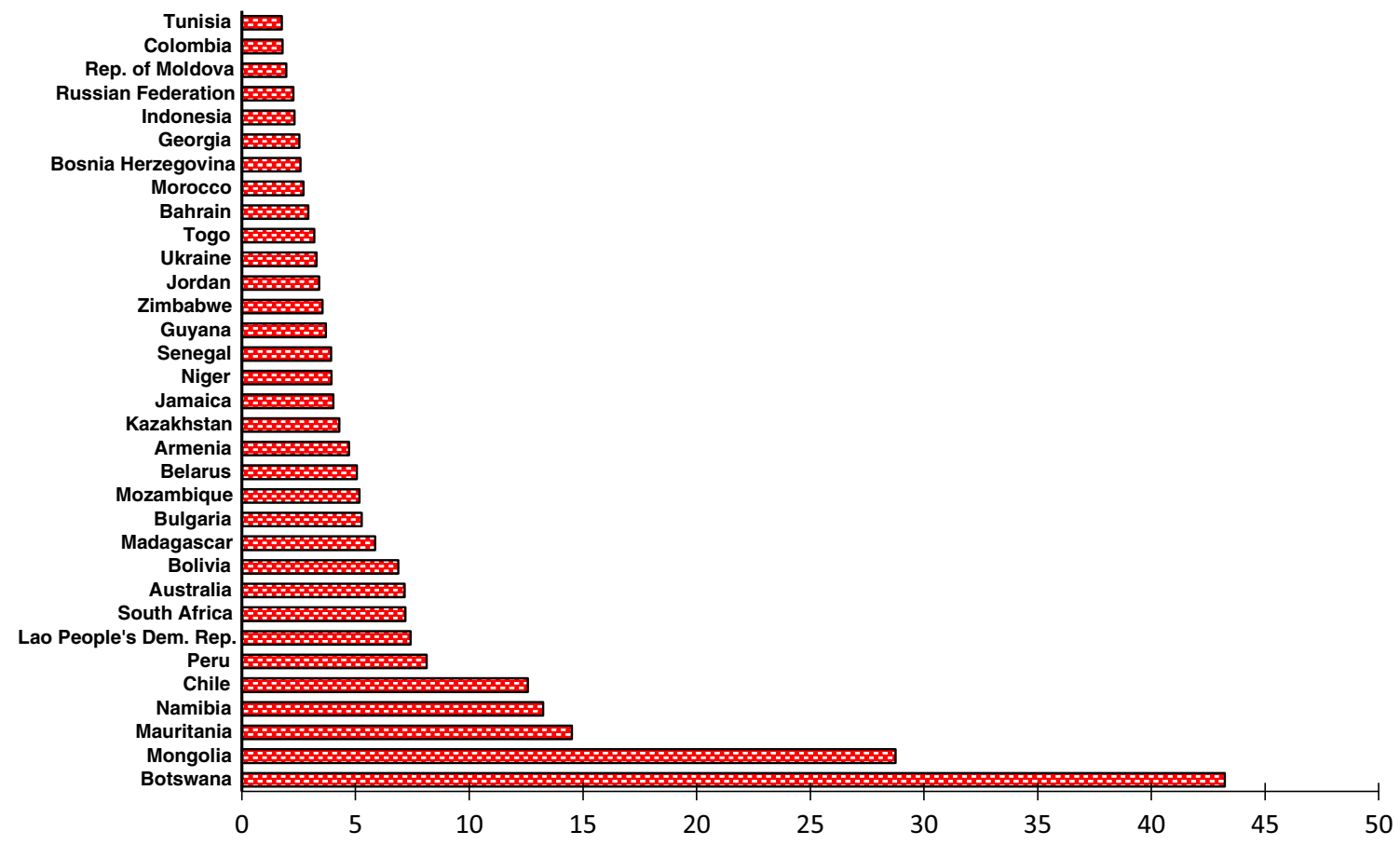

Fig. 5 The percentage share of mineral exports in GDP in 2016. Source: Comtrade and World Development Indicators 
Table 8 Percentage shares of mineral exports in total exports and GDP in 2016

\begin{tabular}{|c|c|c|}
\hline & Exports & GDP \\
\hline Botswana & 92.4 & 43.2 \\
\hline Mongolia & 65.7 & 28.8 \\
\hline Chile & 51.8 & 12.6 \\
\hline Jamaica & 51.6 & 4.0 \\
\hline Namibia & 50.1 & 13.3 \\
\hline Australia & 45.6 & 7.2 \\
\hline Peru & 42.9 & 8.1 \\
\hline Mauritania & 42.4 & 14.5 \\
\hline Lao People's Dem. Rep. & 37.5 & 7.4 \\
\hline Bolivia & 33.0 & 6.9 \\
\hline Niger & 32.3 & 3.9 \\
\hline Armenia & 30.2 & 4.7 \\
\hline South Africa & 28.7 & 7.2 \\
\hline Madagascar & 26.6 & 5.9 \\
\hline Togo & 24.7 & 3.2 \\
\hline Rwanda & 24.0 & 1.2 \\
\hline Georgia & 21.9 & 2.5 \\
\hline Senegal & 21.8 & 3.9 \\
\hline Jordan & 21.4 & 3.4 \\
\hline State of Palestine & 21.3 & 1.5 \\
\hline Zimbabwe & 20.8 & 3.5 \\
\hline Mozambique & 17.0 & 5.2 \\
\hline Colombia & 16.2 & 1.8 \\
\hline Kazakhstan & 16.0 & 4.3 \\
\hline Indonesia & 15.0 & 2.3 \\
\hline Morocco & 12.3 & 2.7 \\
\hline Brazil & 11.9 & 1.2 \\
\hline Bulgaria & 10.8 & 5.3 \\
\hline Montenegro & 10.5 & 0.8 \\
\hline Belarus & 10.3 & 5.1 \\
\hline Russian Federation & 10.2 & 2.3 \\
\hline Rep. of Moldova & 9.9 & 2.0 \\
\hline Guyana & 9.9 & 3.7 \\
\hline United Rep. of Tanzania & 9.6 & 1.0 \\
\hline Bahrain & 8.6 & 2.9 \\
\hline Ukraine & 8.4 & 3.3 \\
\hline Albania & 8.4 & 1.4 \\
\hline Bosnia Herzegovina & 8.2 & 2.6 \\
\hline Cyprus & 7.9 & 0.4 \\
\hline Canada & 7.2 & 1.6 \\
\hline Guatemala & 7.1 & 1.1 \\
\hline Kyrgyzstan & 7.1 & 1.5 \\
\hline Burundi & 6.3 & 0.2 \\
\hline Myanmar & 6.0 & 1.1 \\
\hline Tunisia & 5.5 & 1.8 \\
\hline Benin & 5.2 & 0.2 \\
\hline
\end{tabular}

Source: Comtrade and World Development Indicators

countries where the share exceeded $1.75 \%$ in 2016, and for which the data are available. Table 8 compares the two measures for the countries included in Fig. 4.

In general, the countries with the highest dependence of trade on minerals have a similarly high dependence for GDP; Botswana and Mongolia head both measures. The ordering changes, however, for many other countries. For example, Jamaican and Australian exports are heavily biased towards minerals, whereas their GDP is far less dependent on mineral exports.

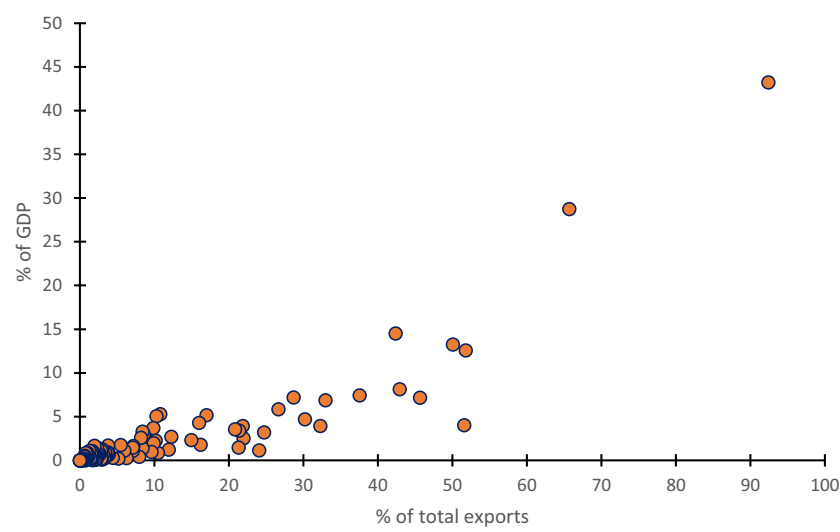

Fig. 6 The relationship between two measures of mineral dependence in 2016. Source: Comtrade and World Development Indicators

The relationship between the two indicators of dependence is summarised for all the countries for which data are available in the scatter diagram of Fig. 6. The two measures are naturally correlated, but the relationship is far from perfect, with an $R^{2}$ of 0.77 in a simple linear regression.

Whilst the share of mineral exports in a country's gross domestic product is one indicator of dependence on the mining industry, it is by no means a complete measure. First, some mineral products will be used domestically, particularly on the wider measure of minerals adopted in this paper. That means that export shares for the countries with domestic markets for their minerals will tend to understate their mineral dependence. Secondly, and probably more important for most mineral producing countries, export turnover is not a reliable guide to the value added by mining. Particularly in less developed countries, there will be various leakages through the mining industries' imports of goods and services. Accordingly, Table 9 compares the share of mineral exports in GDP, as given in Table 8, with

Table 9 Percentage shares of mineral exports in GDP and of mining and quarrying in gross value added

\begin{tabular}{|c|c|c|}
\hline & Value added $\%$ & Export \% \\
\hline Australia ${ }^{\text {(a) }}$ & 6.4 & 7.2 \\
\hline Bolivia & 10.4 & 6.9 \\
\hline Botswana & 21.9 & 43.2 \\
\hline Chile & 8.9 & 12.6 \\
\hline Jamaica $^{(a)}$ & 2.1 & 4.0 \\
\hline Mongolia & 21.8 & 28.8 \\
\hline Namibia & 12.0 & 13.3 \\
\hline Peru & 9.5 & 8.1 \\
\hline South Africa & 7.9 & 7.2 \\
\hline
\end{tabular}

(a) 2015

Sources: Comtrade, World Development Indicators (World Bank, 2018) and UN National Accounts Statistics 
the percentage contributions of mining and quarrying to gross value added for selected countries in 2016.

Again, there are complications because some of the mineral products exported will be treated in National Accounts as products of manufacturing industry rather than of mining. More pertinently, mining and quarrying also embrace oil and gas production, which raises its share in some countries, like Australia, Bolivia and Peru. These qualifications aside, the table does demonstrate that the shares of exports in GDP can exaggerate the overall contribution of mining to economic activity.

\section{Concluding remarks}

This paper is merely descriptive. Its purpose has been to highlight some of the complexities involved in definitions of the minerals industry and to warn against unduly simplistic analyses of minerals trade and dependence. The mining industry embraces far more products than are included in sections 27 , 28 and 68 of SITC Rev. 3, and those sections conversely include a wide range of products that are strictly beyond the purview of the mining industry. In consequence, much public debate is based on partial, and at times misleading, estimates of dependence.

There is clearly ample scope for comparative analysis of the relative merits and uses of different measures of mineral dependence. Such analysis might cover a much wider range of indicators than are included in this paper such as those used by the International Council on Mining and Metals in its Mining Contribution Index (ICMM 2010, 2014, 2016, 2018), or in the WIDER studies (Addison and Roe 2018; Roe and Dodd 2017; Ericsson and Lof 2017). Interesting though it might be, such analysis would probably be much more of academic interest than as a guide to policy. In any case, it is beyond remit of this note.
Open Access This article is distributed under the terms of the Creative Commons Attribution 4.0 International License (http:// creativecommons.org/licenses/by/4.0/), which permits unrestricted use, distribution, and reproduction in any medium, provided you give appropriate credit to the original author(s) and the source, provide a link to the Creative Commons license, and indicate if changes were made.

\section{References}

Addison T \& Roe AR (2018) Extractive industries: the management of resources as a driver of sustainable development. WIDER studies in development economics. Oxford University Press

Ericsson M \& Löf O (2017) Mining's contribution to low- and middleincome economies. WIDER Working Paper 2017/148. Helsinki: UNU-WIDER

International Council on Mining \& Metals (ICMM), (2010) The role of mining in national economies, $1^{\text {st }}$ edition, ICMM, London

International Council on Mining \& Metals (ICMM), (2014) The role of mining in national economies, $2^{\text {nd }}$ edition, ICMM, London

International Council on Mining \& Metals (ICMM), (2016) The role of mining in national economies, $3^{\text {rd }}$ edition, ICMM, London

International Council on Mining \& Metals (ICMM), (2018) The role of mining in national economies, $4^{\text {th }}$ edition, ICMM, London

Roe AR \& Dodd S (2017) Dependence on extractive industries in lowerincome countries: the statistical tendencies. WIDER Working Paper 2017/98. Helsinki: UNU-WIDER

United Nations National Accounts Statistics

United Nations Statistical Division, COMTRADE

United States Geological Survey (2018), Gemstones chapter of the 2015 Minerals Yearbook, US Geological Survey, Washington

World Bank (2018), World development indicators

World Bank (https://data.worldbank.org/indicator/TX.VAL.MMTL.ZS. $\mathrm{UN}$.),

World Metal Statistics 2018 (2018), World Bureau of Metal Statistics, Ware.

Publisher's note Springer Nature remains neutral with regard to jurisdictional claims in published maps and institutional affiliations. 